Отримано: 03 лютого 2020 p.

Прорецензовано: 12 лютого 2020 р.

Прийнято до друку: 17 лютого 2020 р.

e-mail: Anastasiyachebanu@gmail.com

n.e.krasnostanova@gmail.com

DOI: $10.25264 / 2311-5149-2020-16(44)-54-61$
Krasnostanova N., Chebanu A. Complex evaluation of innovative capacity of the industrial enterprise. Наукові записки Начіонального університету «Острозька академія». Серія «Економіка» : науковий журнал. Острог : Вид-во НаУОА, березень 2020. № 16(44). C. 54-61.

\footnotetext{
Head of Chair of Organizations Management Department at the Odesa Regional Institute for Public Administration of the National Academy for Public Administration under the President of Ukraine
}

Anastasiia Chebanu,

Master student at the Odesa Regional Institute for Public Administration of the National Academy

for Public Administration under the President of Ukraine

\title{
COMPLEX EVALUATION OF INNOVATIVE CAPACITY OF THE INDUSTRIAL ENTERPRISE
}

\begin{abstract}
The peculiarities of the structure of innovative capacity of the enterprise are investigated, namely: the essence of the concept of "innovative capacity" is revealed, the components of the system of management of innovative capacity at the enterprise are determined. The analysis and generalization of the existing approaches to determining the structure of innovative capacity of the enterprise is carried out. The characteristic of components of innovative capacity of industrial enterprise is given. The method of complex estimation of innovative capacity of PJSC "Odeskabel" is offered for determination of factors on increase of innovative capacity of the enterprise. The expediency of using the proposed methodology for evaluating the innovative capacity for forming the strategy of development of the innovative capacity of the enterprise is substantiated.

The role of innovative capacity as a decisive factor in increasing production efficiency has been identified, and in the current conditions for enterprises remains one of the priority areas for ensuring their stable economic development. The importance of the impact of innovation on the sustainability of competitive advantages and the effective operation of the enterprise is emphasized by most scientists-economists who are engaged in the problems of scientific and technological progress.

Continuous and comprehensive provision of innovative development of the enterprise ensures a conflict-free transition of the enterprise into a new quality of its life. This means that the enterprise management system must be opened to innovation, provide constant self-learning and development at all levels of its relationship with the environment, as well as at all stages of its life cycle, which in turn will provide the enterprise with a competitive advantage over other businesses.

Assessment of innovative capacity by components: material and technical component; personnel component; infrastructure component; research component; marketing (market) component; organizational and managerial component; financial and economic component; information interface. According to the calculation of the integral index, which equals to 0,579, the innovative capacity of the enterprise corresponds to the average level. According to the results of the analysis of its individual components, it is established that the overall assessment is downplayed by such components as material and technical and marketing. That is, they should be the basis for the development of a set of measures aimed at increasing the level of the enterprise innovative capacity.
\end{abstract}

Keywords: innovative capacity, components of innovative capacity, innovative activity, scientific and technical potential.

\section{Красностанова Наталія Едуардівна,}

Зав. кафедри менеджменту організацій Одеського регіонального інституту державного управління Національної академії державного управління при Президентові України, кандидат економічних наук, дочент

\section{Чебану Анастасія Геннадіївна,}

магістрантка Одеського регіонального інституту держсавного управління

Національної академії державного управління при Президентові України

\section{КОМПЛЕКСНА ОЦІНКА ІННОВАЦЙНОГО ПОТЕНЦАЛУ ПРОМИСЛОВОГО ПІДПРИЕМСТВА}

У статті досліджено особливості структури інноваційного потенціалу підприємства, а саме: розкрито сутність поняття «інноваційний потенціал», визначено складові системи управління інноваційним потенціалом на підприємстві. Проведено аналіз та узагальнення існуючих підходів до визначення структури інноваційного потенціалу підприємства. Надано характеристику складових інноваційного потенціалу промислового підприємства. Запропоновано методика комплексної очінки інноваційного потенціалу ПАТ «Одескабель» для визначення чинників щздо підвищення інновачійного потенціалу підприємства. Обтрунтовано доцільність використання запропонованої методики оцінювання інновачійного потенціалу для формування стратегії розвитку інноваційного потенціалу підприємства.

Ключові слова: інноваційний потенціал, складові інноваційного потенціалу, інноваційна діяльність, науково-технічний потенціал. 


\title{
Красностанова Наталья Эдуардовна,
}

Зав. кафедры менеджмента организаций Одесского регионального института государственного управления Национальной академии государственного правления при Президенте Украины, кандидат экономических наук, доцент

Чебану Анастасия Геннадиевна,

Магистрантка Одесского регионального института государственного управления

Национальной академии государственного правления при Президенте Украинь

\section{КОМПЛЕКСНАЯ ОЦЕНКА ИННОВАЦИОННОГО ПОТЕНЦИАЛА ПРОМЫШЛЕННОГО ПРЕДПРИЯТИЯ}

\begin{abstract}
Исследованы особенности структуры инновачионного потенииала предприятия, а именно: раскрыта сущность понятия «инновационный потенциал», определены составляющие системы управления инновационным потенцииалом предприятия. Проведен анализ и обобщение существующих подходов определения структуры инновационного потенииала предприятия. Представлена характеристика составляюших инновачионного потенииала промышленного предприятия. Предложена методика и расчет комплексной оценки инновационного потенциала ОАО «Одесскабель» для определения факторов, определяюших уровень инновачионного потенииала предприятия. Обоснованна целесообразность использования предложенной методики оценки инновационного потенциала для формирования стратегии развития инновационного потенциала предприятия.

Ключевые слова: инновационный потенциал, структура инновационного потенциала, инновационная деятельность, научно-технический потенцииал.
\end{abstract}

Formulation of the problem. In the current context of accelerating and deepening the process of globalization, the unpredictability of changes that are associated with scientific and technological progress and increased competition in the global market between major players [7], the innovative development is a determining factor for the successful existence and efficient operation of an industrial enterprise, at the same time, one of the basic indicators of the enterprise's susceptibility to innovation shifts is the state of its innovative capacity.

The Blue Ocean strategy was substantiated by Kim Chan and Rene Moborn in 2005 and has not lost its relevance up to date [10]. Considering the variability of the environment and strong competition among enterprises, it is constantly necessary to look for ways to increase the profitability of the enterprise and to develop a strategy for further development that creates the need for innovations [10]. The ability to effectively shape and harness innovative capacity is a decisive factor for an enterprise to enhance its competitiveness not only in the domestic market but also in the world. It is worth noting that the changes that are constantly happening in the world and in the Ukrainian economy today require the owners of the enterprises a strategic vision, which involves the choice of alternatives for future business development, and especially the ability to make the necessary innovative decisions in a timely manner.

The analysis of tendencies of rather slow pace of development of innovation processes in Ukraine shows that domestic entrepreneurs, underestimating the impact of innovative capacity on production efficiency, and for this reason often face a decrease in competitiveness, reduced production and sales, loss of consumers and weakening of position.

Analysis of recent research and publications. Problems of evaluation and management of innovative capacity of enterprises were investigated in the works of domestic and foreign scientists. Issues related to innovation operation and innovation management have been addressed in the works of such foreign scientists as, F. Valenta, M. Heraskin, P. Doyle, P. Drucker, P. Lemerl, B. Twiss A. Thompson, H. Freeman, A. Harman, R. Waterman, J. Schumpeter and others. Important contribution to solving the problems of managing the innovative capacity of the enterprise was made by Ukrainian scientists: M. Bondarchuk, M. Voinarenko, V. Hrishko, V. Stadnyk, V. Zakharchenko, O. Ovechkina, L. Benovska, G. Dobrov, B. Malytskyi, M. Hrinova, S. Grytsulenko, A. Epifanov, N. Chukhray.

However, despite the large number of scientific papers in the field of innovative management, a number of methodological and theoretical problems are still unresolved. There is no precise definition of the concept of innovative capacity of the enterprise, there is no unified methodology for its evaluation, insufficiently developed methodological approaches to managing innovation activity, as well as to determine the level of efficiency of innovative capacity at the enterprise.

The purpose and objectives of the research. The purpose of the proposed research is substantiation the components of a comprehensive assessment of the innovative capacity of the enterprise for practical application while substantiating the necessary directions of innovative development at PJSC "Odeskabel". The purpose of the research is determining the essence of the innovative capacity of the enterprise, to analyze the approaches to the evaluation of innovative capacity, to evaluate the innovative capacity of PJSC "Odeskabel", to substantiate measures to increase the innovative capacity of the enterprise. 
Presenting main material. The development of innovative capacity plays a significant role in the development of the economic system. The concept of "innovative capacity" has become a conceptual reflection of the innovation phenomenon.

The concept of "innovative capacity" was first proposed by K. Freeman [11], which meant ensuring the growth of the system due to a set of measures for the establishment, development, operation and exhaustion of production, economic, social and organizational potentials. Based on the study of scientific literature and the revealed variety of different formulations, the author identified three approaches to the definition of the "innovative capacity" term: as a set of different types of resources; as abilities, opportunities for innovative activity; as a result of innovation.

In order to determine the optimal size and structure of innovative capacity, which must have an effective economic system, as well as to obtain accurate estimates of the impact of innovative capacity on the development of the national economy, it is necessary to have a clear definition, first, the concept of innovative capacity, and secondly, its composition. To this end, it is necessary to clearly identify all the essential factors that determine its dynamics.

Innovation, innovativeness, innovation activity, innovative capacity can be considered as the main factors that determine the scale and intensity of business activity and, ultimately, the degree of its success or failure, regardless of the form, vectors of development of these activities.

One of the important aspects of innovation activity is managing the innovative capacity of the enterprise, which involves using the results of research and development to create a fundamentally new or upgrade existing products, creation and usage new technologies for its production.

Innovations resulting from the realization of innovative capacity can be used in the practical activity of the enterprise, meet the existing needs of consumers and be a potential source of new innovations to meet the future needs of the market.

Few domestic enterprises have strong innovative capacity, but even fewer are capable of realizing it effectively, which cannot but affect their competitiveness and efficiency of economic activity. In the modern conditions of formation, development and realization of innovative capacity is one of the essential factors of sustainable development of domestic enterprises.

In our view, the innovative capacity of the enterprise, being a set of resources for innovation, including hidden opportunities, is the basis of the pyramid of the enterprise competitiveness. Identifying and implementing new ideas can ensure the competitiveness and efficiency of the enterprise over a long period of time. Increasing the competitiveness and efficiency of industrial enterprises through the management of innovative capacity of the enterprise involves the efficient use of all available enterprise resources (material, personnel, financial, material and technical, intellectual) to improve existing ones, as well as the development and implementation of brand new technical, technological, industrial, financial -economic and organizational-managerial approaches and decisions. Effective management of an enterprise's innovative capacity is able to provide it with efficiency and competitiveness both in the near and long term perspective.

"The purpose of evaluating the innovative capacity of the enterprise is the ability to determine the current level of its development, the choice of directions of innovative development and the formation of innovative strategy of the enterprise in the system of formation of strategic alternatives for its development in general, aimed at increasing the resilience and flexibility regarding changes in the environment" [4, p. 132]. The realization of all the capabilities of the enterprise begins with an adequate to the external and internal environment of the overall management strategy. "An innovative strategy, as a component of the overall, requires special attention and alignment with other processes in the enterprise. The main task is to strike a balance between the development of scientific, technical and industrial potentials" [6, p. 165].

At present, the issue of the formation of innovative capacity in the economic literature is receiving a great deal of attention, but the existing information is often fragmentary and contradictory and has no clear interpretation.

Representatives of neoclassical theory of innovation B. Twiss and G. Less evaluated innovation as the "main impetus" of development coming from new consumer goods, new methods of production and transportation, new markets, new organizational forms in industry. In doing so, they also take into account the cyclical nature of economic development. Thus, B. Twiss understands innovation as a process in which an invention or new idea becomes economically meaningful [5].

P. Doyle defines innovation as the creation and delivery of products or services that offer consumers benefits and are perceived by customers as new or more sophisticated. In addition, P. Doyle distinguishes between invention and innovation. The difference, according to the author, is that invention is a new product and innovation is a new benefit. Consumers need not in a new product, but in solutions that offer new benefits [2].

The author A. Grynev views innovative capacity as "... the sum of all available tangible and intangible assets of the enterprise used in the process of innovation" [1]. 
According to O. Lomakin, "the innovative capacity of the enterprise is a measure of readiness to fulfill the tasks that ensure the achievement of the set innovative goal, that is, a measure of readiness for the implementation of the project or program of innovative strategic changes" [3, p. 112].

It should be noted that innovation as the main engine of growth, and innovativeness as a key factor in success in business has repeatedly been noted by management practices. Thus, Abby Joseph Cohen, president of the Goldman and Sachs Institute for Global Studies, notes, "there is a statistically valid link between innovation and growth in living standards" [8].

Confirmation of this dependence is devoted to the study "Innovation and Economic Growth: An Empirical Analysis for CEE Countries" [12], the report of the results of which was held at the 4th World Conference on Business, Economics and Management 2015. All large companies such as Toyota. Samsung, etc., not to mention such recognized innovation leaders as Facebook, Google, Skyscanner, Alibaba Group, Uber, etc., in their strategies highlight the key role of innovation and pay particular attention to the problem of increasing company innovation, stimulating innovation in its employees, counterparties and social communities.

From the above mentioned, it is possible to formulate the definition of innovative capacity, which most fully reflects its essence. Innovative capacity is a system of interacting and interconnected resources of an enterprise that is needed in the process of innovative activities, given their limited nature and possible (positive or negative) impact on the end result of the enterprise. Considering the innovative capacity of the enterprise from the standpoint of a systematic approach, rather than simply as a set of resources, allows to understand more deeply this complex crisis phenomenon and to reveal its main feature, which is manifested in the synergistic effect caused by internal interactions of the elements of the potential.

Innovative activities is of high importance for the degree of risk and uncertainty of obtaining a positive result. Only a stable economic system can finance such work. It is much easier to implement another area of innovation - to acquire innovative products (information) from the one who has already solved these tasks, and to implement them in their production. It is no secret that the long terms of development and introduction of innovations in the domestic macro system have led to the lag of our economy from the economies of the leading countries of the world. In addition, the prolonged periods of development, creation and implementation of innovations have largely contributed to the dispersion of resources intended to provide innovative activities.

In the event that the company makes the decision to independently develop a new product and introduce it into production, then reducing the risk of failure to innovate in the market or reducing it to zero, ideally, can help the proper use of marketing concepts. Although many propositions of marketing theory appear to be rather controversial, especially in terms of scientific and technological progress, the inclusion of marketing resources of an enterprise in its innovative capacity is quite justified because it allows improving its quality.

Thus, the innovative capacity, which is a complex dynamic system, requires characterizing the elaboration of many theoretical, methodological and methodical issues related to the determination of its rational size, structure, assessment of the degree of mutual influence of the macro system on innovative development and innovative activities - on development the macroeconomic system.

In order to develop an effective mechanism for managing the innovative capacity of the studied enterprise PJSC "Odeskabel" it is proposed to evaluate the innovative capacity by the following components:

- material and technical component (characterizes the degree of equipment upgrade and modernization);

- personnel component (characterizes the qualitative composition of engineering and technical personnel (ETP), as well as its age);

- infrastructure component (characterizes the degree of availability of working spaces and specialized equipment of laboratories, research centers, etc.);

- research component (characterizes the level of R\&D expenditures);

- marketing (market) component (shows the degree of production updating of the enterprise);

- organizational and managerial component (characterizes the degree of provision of administrative and managerial staff (AMS) by computer equipment and specialized programs);

- financial and economic component;

- information and interface component.

In our opinion, we should use the system of indicators that most fully and comprehensively characterize the state and level of use of the considered components of the innovative capacity of an industrial enterprise: to calculate the material and technical component of the innovative capacity one should use the indicator of the specific gravity of equipment with a lifetime of up to 10 years, i.e.:

$$
\mathrm{SG}_{\text {equip }}=\mathrm{C}_{\text {upto10 }} / \mathrm{C}_{\text {total }}
$$

where $\mathrm{SG}_{\text {equip }}$ - specific gravity of equipment with a lifetime of up to 10 years 
$\mathrm{C}_{\text {upto10 }}$ - the cost of equipment with a lifetime of up to 10 years, thous. UAH.,

$\mathrm{C}_{\text {total }}$ - the total cost of equipment, thous. UAH.

Perform the calculation of this indicator in accordance with information on fixed assets (see table 1). According to the results, the relative weight of relatively new equipment in the enterprise is 0.126 .

Table 1

Calculation of the indicator of relative weight of equipment with a lifetime of up to 10 years

\begin{tabular}{|l|c|c|c|}
\hline \multicolumn{1}{|c|}{ Name of fixed assets } & $\begin{array}{c}\text { The residual value of } \\
\text { fixed assets, thous. UAH. }\end{array}$ & $\begin{array}{c}\text { The cost of equipment with a lifetime } \\
\text { of up to 10 years, thous. UAH. }\end{array}$ & $\begin{array}{c}\text { Specific gravity of equipment } \\
\text { with a lifetime of up to 10 years }\end{array}$ \\
\hline Buildings and structures & 55725 & 8218 & 0,147 \\
\hline Machines and equipment & 141221 & 15952 & 0,113 \\
\hline Vehicles & 6411 & 850 & 0,133 \\
\hline Ground area & 78815 & 10520 & 0,133 \\
\hline Others & 4290 & 550 & 0,128 \\
\hline Total & 286462 & 36090 & 0,126 \\
\hline
\end{tabular}

- to calculate the personnel component, we use the indicators of the share of specialists with higher education in the total number of administrative and managerial staff (AMS), industrial production unit (IPU) of the enterprise, the specific gravity of AMS younger than 50 years in their number.

The share of specialists with higher education $\left(\mathrm{SG}_{\text {hed }}\right)$ in the total number of administrative and managerial staff of the IPU of the enterprise is determined.

$$
\mathrm{SG}_{\text {hed }}=\mathrm{N}_{\text {hed }} / \mathrm{N}_{\mathrm{AMS}}
$$

where $\mathrm{N}_{\text {hed }}$ - number of specialists with higher education, people.

$\mathrm{N}_{\text {AMS }}$ - number of administrative and managerial staff of IPU, people.

Let us calculate $\mathrm{SG}_{\text {hed }}=85 / 102=0.83$

The specific gravity of AMS younger than 50 years $\left(\mathrm{SG}_{>50}\right)$ in their numbers is determined:

$$
\mathrm{SG}_{>50}=\mathrm{N}_{>50} / \mathrm{N}_{\mathrm{AMS} \mathrm{IPU}}
$$

Let us calculate: $\mathrm{SG}_{>50}=42 / 102=0,412$

Taking into account the equally weighed indicators, the overall assessment of the innovative capacity in terms of personnel $\left(\mathrm{IC}_{\mathrm{p}}\right)$ will be:

$\mathrm{IC}_{\mathrm{p}}=1 / 2 * 0,83+1 / 2 * 0,412=0,621$

- to calculate the infrastructure component $\left(\mathrm{SG}_{\mathrm{Infr}}\right)$, the indicator of equipment provision quality of technological departments and laboratories of product quality control is used. As according to experts' evaluation of the enterprise the laboratories are equipped with equipment for $80 \%$, respectively, the coefficient of equipment provision is 0.8 , that is, $\mathrm{SG}_{\mathrm{Infr}}=0.8$.

- to calculate the research component $\left(\mathrm{SG}_{\text {sc.degree/sc.rank }}\right)$ one use the indicator of the share of scientific and technical specialists who have a scientific degree and scientific rank in their numbers.

The share of scientific and technical specialists who have a scientific degree and scientific rank in the number of such specialists is:

$$
\mathrm{SG}_{\text {sc.degree/sc.rank }}=\left(\mathrm{SG}_{\text {sc.degree/sc.rank }}\right) /\left(\mathrm{SG}_{\text {sc.degree/sc.rank sector }}\right)
$$

where $\mathrm{SG}_{\text {sc.degree/sc.rank }}$ - the share of scientific and technical specialists who have a degree and scientific rank.

$\mathrm{SG}_{\text {sc.degree/sc.rank sector }}$ - the average sectoral indicator of the share of scientific and technical specialists.

Let us calculate $\mathrm{SG}_{\text {sc.degree/sc.rank }}=18 / 85=0,212$

The sectoral average indicator is $30-35 \%$. We take the middle $-33 \%$.

Thus, $\mathrm{SG}_{\text {sc.degree/sc.rank }}=0.212 / 0.33=0.642$

- to calculate the financial and economic component $\left(\mathrm{SG}_{\text {fin.ec. }}\right)$ we use the indicator of the specific gravity of internal R\&D expenditures and the purchasing of technologies in the total expenditures on production, calculated in relation to the average sectoral indicators.

$$
\mathrm{SG}_{\text {fin.ec }}=\mathrm{SG}_{\mathrm{R \& D}} / \mathrm{SG}_{\mathrm{R \& D} \text { sector }}
$$

where $\mathrm{SG}_{\mathrm{R} \& \mathrm{D}}$ - the share of internal $\mathrm{R} \& \mathrm{D}$ expenditures and technology acquisition in total production expenditures, $\%$;

$\mathrm{SG}_{\mathrm{R} \& \mathrm{D} \text { sector }}$ - the average sectoral indicator of internal $\mathrm{R} \& \mathrm{D}$ expenditures and technology acquisition in total production expenditures, $\%$. 
$\mathrm{SG}_{\text {R\&D }}=2701$ thous. UAH. / 100108 thous UAH. $* 100=1.6 \%$

$\mathrm{SG}_{\mathrm{R \& D} \text { sector }}$ indicator for cable enterprises is $3 \%$, so:

$\mathrm{SG}_{\text {fin.ec }}=1.6 / 3=0.53$.

- to calculate the marketing component (SGm) the indicator of the specific gravity of manufacture of products for a period of up to 10 years is used, which is calculated:

$$
\mathrm{SG}_{\mathrm{m}}=\mathrm{V}_{\text {up to10 }} / \mathrm{V}_{\text {total }}
$$

where $\mathrm{V}_{\text {up to10 }}$ - volume of sales of products put into production in the last 10 years, thous. UAH;

$\mathrm{V}_{\text {total }}$ - total volume production, thous.UAH.

The calculation will be performed in table 2 .

Table 2

The calculation of the share of manufacture of products put into production in the last 10 years

\begin{tabular}{|l|c|c|}
\hline \multicolumn{1}{|c|}{ Product name } & Sales volume in 2018, thous. UAH. & $\begin{array}{c}\text { Specific gravity in relation to the total } \\
\text { sales volume }\end{array}$ \\
\hline Fiber-optic cables & 184702 & 0,194 \\
\hline Wires for brushes of electric machines & 82110 & 0,086 \\
\hline $\begin{array}{l}\text { Cables and wires for rolling stock of } \\
\text { railway transport }\end{array}$ & 102200 & 0,107 \\
\hline Field Communication wires & 45500 & 0,048 \\
\hline $\begin{array}{l}\text { Flexible power cables with PVC } \\
\text { insulation and sheath }\end{array}$ & 62016 & 0,065 \\
\hline Heating cables & 28580 & 0,030 \\
\hline $\begin{array}{l}\text { All products are introduced up to 10 } \\
\text { years }\end{array}$ & 505108 & 0,530 \\
\hline Total production & 952921 & 1 \\
\hline
\end{tabular}

Thus, the indicator $\mathrm{SG}_{\mathrm{m}}=0,53$.

- to calculate the organizational and managerial component, it is necessary to use indicators of the number of personal computers per employee of the AMS, as well as the indicator of provision of specialized software.

The number of $(\mathrm{N})$ personal computers per AMS worker is determined by:

$$
\mathrm{N}=\mathrm{N}_{\mathrm{pc}} / \mathrm{N}_{\mathrm{AMS} \text { IPU }}
$$

where $\mathrm{N}_{\mathrm{pc}}$ is the number of personal computers installed in the administrative building, units.

$\mathrm{N}=48 / 102=0.47$

The indicator of specialized software provision $\left(\mathrm{N}_{\mathrm{ss}}\right)$ is calculated as follows:

$$
\mathrm{N}_{\mathrm{ss}}=\mathrm{N}_{\text {ssinstalled }} / \mathrm{N}_{\text {ssrequired }}
$$

where $\mathrm{N}_{\text {ssinstalled }}$ - installed specialized software;

$\mathrm{N}_{\text {ssrequired }}$ - specialized software required;

Out of the 10 required software packages, 9 programs are installed and used in the enterprise, but there is a need to buy a CRM system to facilitate the work with consumers. Therefore, the indicator will be:

$\mathrm{N}_{\mathrm{ss}}=9 / 10=0,9$

Taking into account the equal wight of these indicators, the overall assessment of innovative capacity by organizational and managerial component $\left(\mathrm{SG}_{\text {org.mng }}\right)$ will be:

$\mathrm{SG}_{\text {org.mng }}=1 / 2 * 0.47+1 / 2 * 0.9=0.685$

- to calculate the information and interface component $\left(\mathrm{SG}_{\mathrm{ii}}\right)$, it is recommended to use the indicator of completeness of information (Kci), calculated as the ratio of the amount of information available in the decisionmaking person to the total amount of information needed to make a well-founded decision. Since the company has a complex linear-functional structure, its managers do not always have the full amount of information they need. According to experts, the degree of completeness of information in such structures can vary from 60 to $80 \%$. If you select the middle of the class, this indicator will be 0.7 .

For a comprehensive system for assessing the level of innovative capacity of an industrial enterprise, it is proposed to use an integral indicator, which is calculated which is calculated by determining the weight (Wi) of each of the components of the innovative capacity, and then to calculate the integral estimate of the innovative capacity as a weighted average.

Once all the components have been identified, we can set the level of innovative capacity. The calculation is performed in Table 3. It is necessary to determine the weight of each of the components of the innovative capacity. Suppose that all components have the same meaning, that is, the weight of each is $1 / 8$. 
We calculate the integral estimate of the innovative capacity of the enterprise as a weighted average of components:

$\mathrm{SG}_{\text {ice }}=1 / 8 * 0,126+1 / 8 * 0,125+1 / 8 * 0,8+1 / 8 * 0,642+1 / 8 * 0,53+1 / 8 * 0,685+1 / 8 * 0,53+1$ $/ 8 * 0,7=0,5794$

Table 3

Setting the level of innovative capacity

\begin{tabular}{|l|c|c|c|}
\hline $\begin{array}{c}\text { Components of innovative } \\
\text { capacity }\end{array}$ & $\begin{array}{c}\text { Evaluation of the enterprise } \\
\text { by the component }\end{array}$ & $\begin{array}{c}\text { The specific gravity of the } \\
\text { innovative component }\end{array}$ & $\begin{array}{c}\text { Weighted estimate of the } \\
\text { innovative component of the } \\
\text { enterprise's innovative capacity }\end{array}$ \\
\hline Material and technical & 0,126 & 0,125 & 0,0158 \\
\hline Personnel & 0,621 & 0,125 & 0,0776 \\
\hline Infrastructure & 0,8 & 0,125 & 0,1 \\
\hline Research & 0,642 & 0,125 & 0,0803 \\
\hline Marketing & 0,53 & 0,125 & 0,0663 \\
\hline $\begin{array}{l}\text { Organizational and } \\
\text { management }\end{array}$ & 0,685 & 0,125 & 0,0856 \\
\hline Financial and economic & 0,53 & 0,125 & 0,0663 \\
\hline Information and interface & 0,7 & 0,125 & 0,0875 \\
\hline Total & \multicolumn{2}{l}{0,5794} \\
\hline
\end{tabular}

According to the results of the calculation, the level of innovative capacity $(0,5794)$ is at the average level. The analysis of individual components of innovative capacity will allow clarifying which parameters make the overall assessment lower.

To present the results of the evaluation of the innovative capacity of the enterprise in a visual form, it is possible to construct a diagram in the polar coordinate system. The angles will correspond to the weight characteristics, and the radius vectors - characterize the levels of components of the innovation potential (Fig. 1).

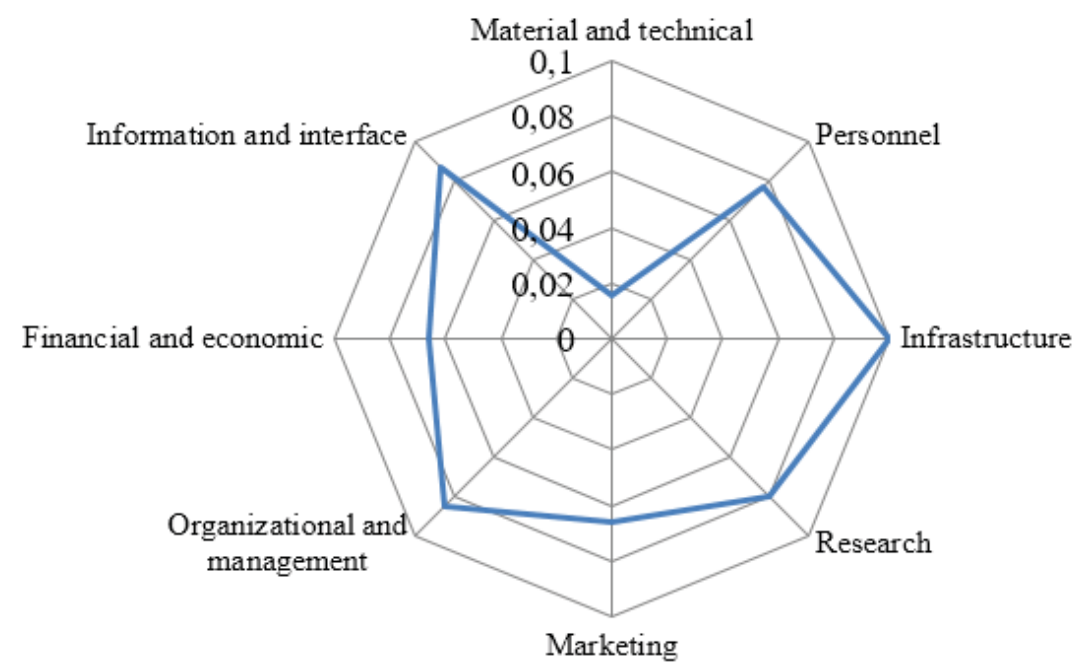

Fig. 1. Innovative capacity profile of PJSC “Odeskabel”

As we can see from the figure, the innovative capacity of the enterprise is of critical importance for such components as material and technical and marketing. That is, they should be the basis for the development of a set of measures aimed at counteracting threats and increasing the level of innovative capacity of the enterprise, and, accordingly, expanding its adaptive capacity to changing conditions of economic activity, creating conditions for stable functioning and development. It is the material and technical and marketing component that will lead to improvement of the innovative capacity of the enterprise.

Conclusions. One of the most important components of an innovative development management system is innovative capacity, the formation of which is a conceptual reflection of the process of innovative development.

Determining the structure of innovative capacity is an important problem in forming a comprehensive evaluation of the innovative capacity of an industrial enterprise. The composition of the evaluation indicators should provide the necessary and sufficient information on the state of the innovative capacity and its individual components 
in order to make timely and objective management decisions regarding the further effective management of its innovation development.

The purpose of a comprehensive evaluation of the innovative capacity of an industrial enterprise is the ability to select and implement a strategy of innovative development, which allows increasing its level of competitiveness in the market. Comprehensive assessment of the level of innovative capacityl of the enterprise will allow:

- adequately assessing its readiness and adequacy for innovative development;

- analyzing and predicting trends of enterprise development;

- identifying its strengths and weaknesses;

- justifying directions and concrete measures for the choice and formation of strategy of development of innovative capacity and the mechanism of its realization.

\section{References:}

1. Гриньов, А. В. Оцінка інноваційного потенціалу підприємства. Проблеми науки. 2003. № 12. С. 12-17.

2. Дойль, П. Менеджмент: Стратегия и тактика / пер. с анг. Т. Карасевич. Санкт-Петербург: Питер, 1999. $560 \mathrm{c}$.

3. Ломакин, А. Ю. Инновационный потенциал как основа стратегии развития предприятия. Проблемы и перспективы экономики и управления: материалы II междунар. науч. конф., (г. Санкт-Петербург, июнь 2013 г.). Санкт-Петербург: Реноме, 2013. С. 113.

4. Овєчкіна, О. А., Іванова К. В. Огляд методів оцінки рівня інноваційного потенціалу економічних суб’єктів. Економічний вісник Донбасу. 2007. № 4. С. 130-139.

5. Твисс, Б. Управление научно-техническими нововведениями. Москва: Экономика, 1989. 271 с.

6. Шаманська, О. І. Стратегічне планування інноваційної діяльності в системі ресурсного потенціалу підприємства. Актуальні проблеми економіки. 2009. № 6 (96). С. 165.

7. Підсумки Всесвітнього економічного форуму у Давосі (2019): висновки для України. Аналітична записка. URL: http://old2.niss.gov.ua/articles/3342/ (дата звернення: 01.01.2020).

8. Cohen, A. J. Innovation and Economic Growth. URL: http://www.goldmansachs.com/our-thinking/archive/ archive-pdfs/gsr.pdf. (Last access: 03.01.2020).

9. Freeman, C. The National Systems of Innovation in historical perspective. Cambridge journal of economics. 1995. № 19. pp. 5-24. - http://www.forschungsnetzwerk.at/downloadpub/1995_Freeman_NSI_historial_perspective. pdf. (Last access: 03.01.2020).

10. Kim, W. C., Mauborgne, R. A. Blue ocean Strategy : how to create uncontested market space and make competition irrelevant. Boston : Harvard Business Review Press, 2015. 287 p.

11. Pece, A., Olivera, E., Florina, S. Innovation and Economic Growth: An empirical Analysis for CEE Countries. Procedia Economics and Finance. Vol. 26. 2015. pp. 461-467. URL: https://doi.org/10.1016/S2212-5671(15)00874-6. (Last access: 03.01.2020). 